\title{
Hearing the transformative potential of metaphor in scripture? Honouring J. Wentzel van Huyssteen
}

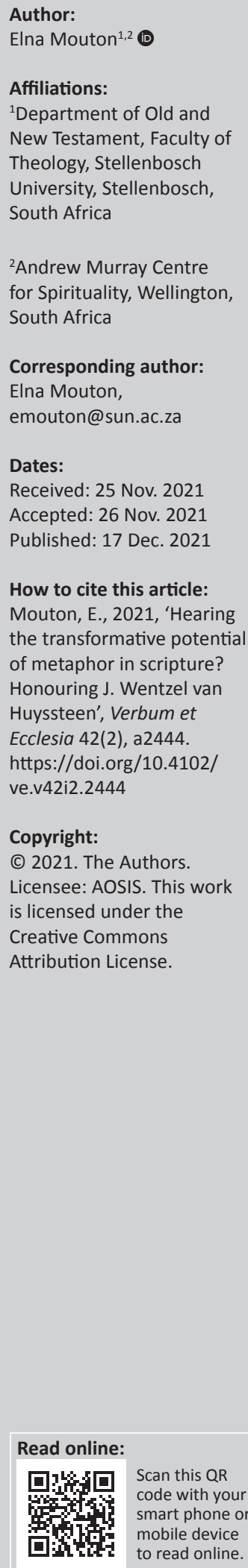

Christians worldwide are (re)discovering the power of scripture in their daily lives, especially in the context of the COVID-19 (coronavirus disease 2019) pandemic. The present turbulent time provides the biblical sciences an opportunity to support other theological disciplines and the church to search for ways scripture can give encouragement to people. The argument in this article is that the power of biblical writings lies in their metaphors which open an alternative moral world. For the appropriation of scripture in new contexts, the transformative potential of J. Wentzel van Huyssteen's metaphorical hermeneutic is explored as a framework. The article gives a brief overview of the influence of his work as a mentor, colleague and friend.

Intradisciplinary and/or interdisciplinary implications: The article focuses on the dynamic nature and intentions of New Testament Studies (intradisciplinary aspects), and uses the philosophical hermeneutic of a systematic theologian as well as insights from literary theory and cultural anthropology to support the argument and open up interdisciplinary discourse.

Keywords: New Testament Studies; ethics of interpretation; transformative potential of metaphor; J. Wentzel van Huyssteen's hermeneutic; 'hearing the word'.

\section{Introduction ${ }^{1}$}

As the first chaplain at the Andrew Murray Centre for Spirituality in Wellington, South Africa, since 2019, I am challenged to build on centuries of biblical interpretation and contemplation in church and cultural contexts worldwide. The purpose of the Centre is to create a space conducive to being silent, 'hearing the word', aware of one's own presence in the presence of God and that of others. The bible serves as the primary authoritative text in the daily rhythms and rites at the Centre.

My reading of the bible ${ }^{2}$ was formed and challenged by my exposure to various cultural, church and academic contexts (Mouton 2002:1-6). Inspired by the wisdom of 'regular readers', students and colleagues, I developed interest in the 'authority' of these texts over time and within different cultures. The paradoxical nature of biblical texts as both 'word of God' and products of human interpretation from within male-dominated cultures challenged me (cf Schneiders 1991).

A general insight into the relational nature of knowledge, and the metaphorical language in particular, opened the way for me to appreciate the life-giving potential of these texts within their cultural 'constraints'. At the same time, I became increasingly aware of the devastating effect these texts have when they are interpreted as 'word of God' in an unnuanced, one-sided and absolutistic way. For me, this rigidity changed into a crucial challenge to consider the rich yet complex nature and intent of these texts. For this reason, I am concerned with the poignancy of rigid biblical interpretation - its power to convince, the way it is received and the effect it has on the lives of people and faith communities (Mouton 2006).

It is in this regard that the life and work of J. Wentzel van Huyssteen as mentor, colleague and friend became a lasting influence on my thinking as a biblical scholar. Van Huyssteen is a South African-born systematic theologian, who served as first head of the Department of Biblical and Religion Studies at the former University of Port Elizabeth (UPE), now the Nelson Mandela University (1972-1991). He was my lecturer in Systematic Theology when I enrolled for an MTh

1.This is a shortened and reworked version of my inaugural lecture as professor in New Testament Studies in the Faculty of Theology, Stellenbosch University, on 22 March 2005 (cf. Mouton 2006).

2.Because any interpretation is such a relative enterprise, and the general inclination is to absolutise and abuse authority - especially 'biblical authority' - I write 'bible', 'scripture' and 'word of God' in lower case. 
in New Testament at UPE in 1985. His teaching and writing influenced me greatly regarding the quest for ultimate meaning, the relational nature of all knowledge, the beauty of life in general, and the metaphorical nature of theology. I was interested in reading the New Testament texts ethically and intra-culturally, particularly with regard to women's lives on the continent of Africa. I was intrigued by his nuanced, sophisticated hermeneutic on the fringe of various cross-disciplinary discourses. He encouraged me to submit my first article for publication in an academic journal, to attend international conferences, and to develop my own voice as a New Testament scholar. He introduced me to authors (in the field of Systematic Theology) and his extended network of international colleagues - Mercy Amba Oduyoye, Sallie McFague, David Tracy, Mark Kline Taylor, Miroslav Volf, Niels Gregersen, and Bill Eerdmans (publisher and friend). During 1990-1991 we were colleagues in the Department of Biblical and Religion Studies before he and his wife Hester moved to the USA. At Princeton Theological Seminary, he did the pioneering work as the first (and until now, the only) James I. McCord Professor of Theology and Science, specialising in the philosophy of science and religious epistemology. In the USA and further afield, he was acclaimed for his unconventional contributions to interdisciplinary discourses between theology and science. He worked and lived in the USA for almost 23 years (1992-2014) before returning to retire in South Africa.

I will focus with broad strokes on contexts and processes associated with the reception of biblical texts in general. Through the ages - at least until the European Enlightenment Christian believers listened to, interpreted and appropriated the bible in a great variety of ways, wanting to understand their everyday lives. They were not so much interested in the biblical texts itself, or in what we today know as the academic or intellectual study of the bible. They were interested in scripture as canon, as norm - a guiding lamp, a light for their path. Without appropriating the bible to their everyday needs, challenges, sufferings, fears and hopes, the reading process, for many, would simply be incomplete and pointless. For them, the bible would be useful only insofar as it helped them to live faithfully coram Deo (cf Smit 1998a:275-291).

Since the Enlightenment, however, the attitude towards the bible changed. Different questions were asked. Paradoxically, people became more interested in this collection of ancient documents as an object for study, distinguished and separated from understanding life by means of it. The questions being asked of the bible were increasingly of a theoretical and 'objective' nature, instead of being personal, existential, and related to everyday life of its recipients (Smit 1998a:291-296).

We are living at a time in which Christianity is passing through a phase during which believers worldwide are (re) discovering the power of the bible for their daily lives. There is evidence of this trend in South Africa and especially in the rest of the African continent (cf eds. West \& Dube 2000). The trend has recently been intensified by the devastating effects of the COVID-19 (coronavirus disease 2019) pandemic. The moment affords theology in general, and the biblical sciences in particular, an opportunity to assist the ecumenical church in all its manifestations to make sense of the human story amid disaster and loss, at the same time accounting for the ways in which scripture functions 'authoritatively' in the church's ethos and decision-making. What makes this a particularly moral issue, is the influence these texts have on how people understand God, as well as their own identities, and daily choices in personal and public life.

The escalating discourse worldwide about the functioning of scripture in the Christian ethos and ethics needs to be looked at within this context (cf Mouton 2002:7-13). It is part of a much broader discussion among literary scholars on 'the ethics of interpretation', which requires that people take responsibility for the way they read - specifically to the nature of the literature involved and the socio-historical contexts within which it is received. ${ }^{3}$ This challenge becomes more urgent when it comes to canonised (religious) texts, which are read with the anticipation of communicating new life and hope. This is by no means a straightforward issue because of the variety of ways in which the bible has been interpreted and appropriated during the course of the human story. ${ }^{4}$ It confirms the relational nature of all human knowledge, including interpretations of the bible (cf van Huyssteen 1987:15-51). An 'ethics of New Testament interpretation' would thus be challenged to account for the dynamic yet complex nature of authority and intensions of these texts, and their appropriation in terms of the faith experiences and needs of present-day readers/audiences.

According to their multidimensional nature and purpose, these texts necessarily invite multiple questions (cf n.3). In the context of honouring van Huyssteen's life and work, I will focus on the following. Firstly, how do the New Testament texts refer to God as ultimate reality? Secondly, where metaphorically speaking, does redescription of reality by their receivers occur? And finally, of what use are exponents of New Testament Studies to other theological disciplines' and the church's social responsibility and public ethos?

I start with some short comments on the origins of the New Testament texts. In general, one can say that these texts are the result of human activity wanting to understand transforming

3.To describe the reading process as particularly ethical, basically refers to the wide range of choices readers have to make: '(T)he ethics of interpretation asks (i) who (that is, which individual or group) reads (ii) which Bible (that is, what view of the text does the interpretive community hold, what authority does it grant the text) (iii) how (that is, using which methods) and (iv) why (that is, whose interests are at stake, what does the interpretive community want to achieve with their acts of interpretation?' (Botha 1994b:4-5; cf Schüssler Fiorenza 1988; Smit 1990a, 1990b 1991a, 1998b; Patte 1995). The discussion further distinguishes between Christian ethics as a critical, scientific discipline and Christian ethos as 'the habitual character and disposition of a group' (Smit 1991b:52, 1992:303-317; cf Meeks 1993:4). The difference between ethics and ethos often has something to do with the difference between an ethics of Doing (Sollen) and an ethics of Being (Sein). For some time contemplative theologians have argued for a shift in emphasis towards the latter towards the formation of the moral identity and ethos of a group (cf Hauerwas 1981, 1985a, 1985b). According to this view, an ethics of responsibility (Doing) presupposes an ethics of relationality (Being). What we do is the result of who we are (cf also Mouton 2002:243-251; Tödt 1977). This shift is also the rationale behind the existence of the Andrew Murray Centre for Spirituality.

4.See Smit (1994a) for a useful typology of historical paradigms in Christian ethics, with dominant questions being asked during those phases. A major implication of such a historical overview is that the bible has been used in many different ways in such a historical overview is that the bible has been used in many different ways in being put to it (cf Botha 1994a:40-42; Mouton 2002:201-219; Smit 1998a, 1998b). 
experiences with Jesus of Nazareth (cf Mouton 2001:121-122). The resurrection faith of the early followers of Jesus, for example, was rooted in paradox; it needed interpretation. In diverse and changing social contexts, the uninterrupted experience of God's life-giving Spirit was a continual challenge to (re)interpret traditions and (re)imagine the future.

Any interpretation, including the interpretation of 'religious' experience, obviously happens in the light of available symbols. This would have been the situation for the early followers of Jesus. It was unavoidable for them to interpret new experiences and changing circumstances in the light of a pluralistic first-century Mediterranean symbolic world. The Greco and Roman (specifically Hellenistic) culture, as well as the religious symbols of Judaism were complex and diverse. The rapid growth of the Jesus movement required adjustment to new settings. In the process they did not invent a new language, but rather reinterpreted, rearranged and reappropriated available symbols and traditions (cf Johnson 1999:5, 35-38). ${ }^{5}$

Similar processes of experience and interpretation continued during the collection, selection and canonisation of the New Testament documents by the early church fathers. Through these processes the early church affirmed that those writings especially in their being addressed to, and conditioned by particular historical contexts - obtained enduring authority and relevance for the church. ${ }^{6}$ It is in their diversity of settings, genre and style that these texts addressed different contexts through centuries. This is why the whole collection of diverse and complex writings has to be kept alive if the church is to affirm its identity.

An interactive dynamic like this provides New Testament Studies with a useful framework - to continue the interpretive processes of the early church, critically accounting for our own interpretation in different times and places.

\section{How do these texts refer to the ultimate reality called 'God'?}

The Christ event was to amplify and reshape all previous experiences and interpretations of the God of the Hebrew scriptures (Mouton 2006:57-60). It would challenge the early (and later) followers of Jesus radically to revise their everyday lives within a faith relationship with the living God through Jesus Christ and the Spirit. If Jesus (as interpreted by the New Testament texts) opened up new ways and directions of speaking about God, humanity and society, how was it supposed to be executed?

5.For those participants in the Judeo-Christian story - both in the Jewish scripture and the New Testament - the cult, its festivals and specifically its liturgy provided the interpretive space, the frame of reference, the horizons for a reality within which they collectively expressed and cultivated their vision of, and trust in a living God. Through rituals of public worship, they were constantly reminded of how people experienced and described God's presence in the past, and encouraged to do likewise in the present.

6.It is of crucial importance to acknowledge the dynamic nature of these texts, not only in terms of the processes of interpretation represented by them, but also by the ongoing processes of interpretation and sense-making stimulated and facilitated the ongoing processes of interpretation and sense-making stimulated and facilitated
by them. The imperative of such ongoing processes is in fact implied in the very by them. The imperative of such ongoing processes is in fact implied
nature of these texts (Fowl \& Jones 1991:36-44; Lategan 1982:48-50).
The ability to explore, know and describe reality is an awesome challenge to human beings. Perhaps more remarkable, is the ability of human imagination to redescribe reality, to rename experiences, and to retell their stories from new perspectives. This involves the human ability to speak metaphorically - to recognise new possibilities and to make new connections between familiar images and experiences (Lategan 1994:21; Mouton 2006:60-64; van Huyssteen 1986:158-168, 1987:26-31, 1997:169-178).

Metaphorical language distinctively extends throughout the New Testament writings. Literary tools such as genre (narrative, parable, poetry, apocalyptic symbols), liturgy, art, tradition, and people - all function as rhetorical instruments for redescribing reality. The early Christians, for example, referred to God as redeemer in Jesus Christ; to Jesus as son of God, lord (ó kv́pıós) and saviour; witnessed to the Spirit as the seal of God's ownership of them; to themselves as the body of Christ, as God's household and holy temple. They re-imagined and renamed their understanding of God and their daily life experiences from the new perspective of the Christ event. ${ }^{7}$ This way metaphor can function as a powerful, reorienting lens showing a renewed self-understanding and ethos, creating a perception of the past, present and future.

The appeal of metaphor to me is its imaginative and transformative characteristics, its ability to refer to, shape and make sense of an alternative reality. According to Ricoeur $(1975,1976: 89-95)$, the transformative power of a text lies in its ability to suggest and mediate this alternative reality, creating the possibility of opening up a 'proposed world' which readers can choose to adopt or inhabit and identify with. In this way a text may reveal new possibilities - new ways of looking at matters, new ways of relating to people, new ways of thinking and behaving (see Lategan 1992:154, 1994:131-133; Thiselton 1992:351-372; van Huyssteen 1987:25-26, 1997:169-174). In this way a text has a convincing advance towards renewal, inviting people to re-imagine their life stories, and to inhabit it as the real world for them (cf Lategan 1996; van Huyssteen 1987:38-51).

The referential and transformative potential of a text corresponds with the notion of the 'implied reader' as 'the reader we have to be willing to become in order to bring the reading experience to its full measure' (Vorster 1989:25). Since the development of reader response and reception theories, Wolfgang Iser's concept of the 'implied reader' became a powerful tool in describing the role of audiences/ readers in the process of understanding. The implied or textually defined reader refers to:

7.cf van Huysteen (1987:26). New Testament metaphors may serve as 'windows' (albeit hazy) through which the processes of identification, estrangement, and reorientation - typical of the image-making capacity of the human mind - can be viewed. Any creative act of interpretation, discovery, decision-making, transition or transformation can be recognised as the imaginative combination and synthesis of transformation can be recognised as the imaginative combination and synthesis of the familiar into new wholes (McFague 1982:35-36), which is a redescription of reality (Ricoeur 1975:122-128, 1976:45-69, 1980:26). These notions provide important insight into the processes through which the Christian story may impact on audiences of New Testament texts by continuously reorienting their understanding of God, themselves and their ethos as followers of Jesus Christ whose life always reorders, shocks, and upsets familiar, conventional preconceptions and understandings of God. 
The anticipated role a potential reader is expected to play in order to actualize the text ... (It) is a device to engage the real reader by offering a role to be played or an attitude to be assumed. (Lategan 1989:5, 10)

In this sense metaphors are important lenses, clues, signals or shifting devices by means of which an author can guide her/ his audience towards adopting a preferred position, or inhabiting a new moral world.

What effect was the language of the New Testament writings supposed to have on their audiences? What was their implied rhetorical function? (cf Schüssler Fiorenza 1988:13-17). It seems that these texts were intended to focus their audiences' attention on the God of Jesus Christ and the Spirit - the proclamation of God's pathos, God's liberating and healing grace towards humankind, but also as an invitation to identify with God's revelation and purpose for creation in Christ. According to McFague (1982:31-66, 90-194), the heart of the drama of Jesus' death and resurrection is the tension it creates between the accepted ways of relating to God and others, and a new way of living in the world.

For the church to identify with, and inhabit, the strange alternative world of the New Testament writings is an ongoing, interactive process. It involves the wonder of a (re) creating Sender-God's initiative and the receiving of God's grace by individuals and faith communities. It is as much a gift of God's grace as a faithful hermeneutical choice:

In a cooperative shared work, the Spirit, the text, and the reader engage in a transforming process, which enlarges horizons and creates new horizons. (Thiselton 1992:619)

Therefore, for New Testament Studies to give account of the nature of these writings and their reception in new times and places - as a life-giving and sense-making activity - the authority of these texts has to be (re)focused and (re)structured within the settings of uninterrupted interaction between God's Spirit, their diverse textual dimensions, as well as the interests, dreams and fears of contemporary faith communities. Such an approach will embrace the many dimensions of the hermeneutical circle, and will be truthful to the dynamic nature and purpose of these texts. Surprisingly, the spiral movement between the Spirit, scripture and the concrete needs of current audiences is also crucial for unlocking the liberating meaning of those ancient canonised texts. It is their power to facilitate, persuade and affirm new possibilities, to encourage, console, and to invite, move and challenge their receivers to (re)imagine these texts authoritatively.

\section{Where do such metaphorical acts of redescription occur?}

The transforming and authoritative power of the New Testament writings are shown within the interaction between Spirit, text and context. This richness and complexity already indicated the attempts of the early followers of Jesus to interpret and understand their life experiences. The continuous process which had to show them how to match their new identity in Christ with a lifestyle and language worthy of their calling, took place in the creative, liminal strain between their understanding of Torah and their memory of Jesus.

The concept of 'liminality' was introduced by French anthropologist Arnold van Gennep, who used the term 'rites of passage' in connection with the ceremonies and rituals performed at different stages in the life cycle of individuals and groups (birth, puberty, marriage, parenthood, retirement and death). These rites serve principally to provide guidance for the responsibilities encountered in the new phase (Van Gennep 1960:1-13, 21). Van Gennep (1960:15-25, 192-194) distinguished three types of rites: rites of separation from a previous world, rites of transition, and rites of incorporation into a new world. Using the Latin word limen (threshold), he respectively calls these rites pre-liminal, liminal and post-liminal. In the fields of cultural anthropology and sociology, the notion of liminality has since been developed further by several scholars, in particular by North American anthropologist Victor Turner. It has also been adapted and appropriated by theologians such as Gerald Arbuckle and Leo Perdue, both with reference to Victor Turner, and Mark Kline Taylor, with reference to anthropologist Paul Rabinow. Taylor (1990:199-208), a systematic theologian from Princeton (and former colleague of van Huyssteen), develops liminality - together with 'admiration' - as a Christian reconciliatory strategy for dealing with human differences. He observed:

[L]iminality is the term I reserve for the kind of life known 'betwixt and between' differentiated persons, groups or worlds. This is an experience of the wonder, the disorientation and discomfort that can rise when one is suspended between or among different groups or persons (Taylor 1990:200; emphasis mine).

Taylor describes the liminal space between cultural (including gender) boundaries as a difficult, fragile, risky and trying experience, of which the ambiguities and strains are not easily tolerated. At the same time, the liminal encounter represents a dynamic and dialectic process wherein no one remains static. As new alliances are constructed in the interaction between different worlds, people's moral identities and lifestyles are reconstituted by it. From within this space their hope for the future and their courage to live faithfully in the present would be shaped. The authors of the New Testament writings facilitate such processes by constantly reminding their readers of the privilege and associated ethos of their new position in Christ, strikingly different from who they were before. ${ }^{8}$

8.As the medium between radically different modes of existence, the New Testament writings metaphorically function as thresholds between inherited traditions and new interpretations of reality. It is the unavoidable challenge to account for their faith in a crucified, exalted Christ that provided the New Testament authors and their audiences with the stimulus to redefine their humanity and moral existence in different times and places, under many diverse circumstances (cf McFague 1982:154; Mouton 2003). It was the creativity of such 'in between', liminal stages inspired by the radical presence of God's resurrected Christ and life-giving Spirit inspired by the radical presence of God's resurrected Christ and life-giving Spirit that led to the production of these texts in the first place. The addressees' movement from one world to another, from a position 'outside Christ' to being in Christ' (to use typical Pauline language), is presented from various cultural contexts and times as a continuous wrestling to understand, a risky process with significant analogies to van Gennep's stages of separation, transition, and incorporation. However, the structure of their rhetoric rather seems to resemble a cyclical movement of continuous reinterpretation and renewal within liminal space. 
This movement from one insight (position) to another can be described as the typical metaphorical processes of orientation, disorientation (alienation) and reorientation. It is in this context that I find the concept of 'liminality' particularly helpful for describing the complex and ambiguous interaction between senders, texts and receivers, which represents the 'epicentre' of textual communication in general and New Testament Studies in particular. Liminality involves experiences of both the wonder and discomfort when one is suspended between different groups, persons or viewpoints. These are processes implied by the very nature of the New Testament writings themselves. The majority of their implied receivers found themselves within liminal or transitional contexts - characterised by comprehensive changes in their thinking, as well as changing political, economic, social and moral conditions in the firstcentury Mediterranean world (cf Meeks 1986, 1993). The creativity, tension, paradox and risk of liminal spaces are ironically implied by these texts as the most appropriate context for moral development and spiritual growth (Mouton 2006:64-66).

If the epicentre of New Testament interpretation is characterised by such a rich yet complex dynamic. It certainly provides New Testament Studies with important clues towards the ethos and pathos of its task. If, as we have seen, the authority of these texts lies in their metaphorical ability to disclose new perspectives on reality and new ways of living in the world, New Testament Studies is challenged to do likewise - to mediate the discernment of such an alternative world, a world characterised by God's radical presence in Jesus Christ and the Spirit. It is in this regard that I am convinced that New Testament scholars are called to support other theological disciplines and the church - particularly in its social responsibility - where it becomes a liminal place, boldly stepping into risky spaces, facilitating diverse dialogue and divergent discourses. ${ }^{9}$

In such a process, an appropriate first response would be to take the multifaceted (rich yet ambivalent) reception of the bible in Africa seriously. It involves the (growing) importance of the bible for Africa, and also the importance of African contexts for the interpretation of the bible. It has many and far-reaching implications for New Testament scholarship in Africa. It needs to recognise and affirm the contribution of Christian spiritualities in Africa - for example, as embodied by The Circle of Concerned African Women Theologians. They are characterised by their passion for wholeness of life (opposing divisions between 'secular' and 'sacred', 'spirit' and 'body', the 'self' and the 'other', 'male' and 'female', 'culture' and 'nature'), regarding community life as central to all meaning, and respecting the integrity of creation (Phiri 2004; cf Mouton 2006:67-76).

\footnotetext{
9.In continuation with the rich yet fragile nature of these texts I wish to argue that liminality be embraced as an essential characteristic of the Christian life, of theology in general, and of developed by related disciplines such as anthropology, sociology, literary science, classical and modern rhetoric, history, philosophy, hermeneutics - and particularly the arts - would therefore be needed for the ongoing explorations of the communication processes represented and stimulated by these texts.
}

Secondly, New Testament scholars may serve other theological disciplines and the church best by simply speaking more humbly and provisionally about the surprising reality of a compassionate, vulnerable and impartial God's presence as revealed in the New Testament writings in a complex world.

\section{Are we New Testament scholars (still) of any use?}

All human expressions and interpretations of the Christian faith are fragile and all too often fragmented embodiments of the mystery of God revealed in Jesus Christ. None of those interpretations (whether symbols, rites, stories or practices) can adequately reflect the rich unity and koinonia of the ecumenical church worldwide. New Testament Studies are therefore not the prerogative of a privileged or marginalised few. Its rich yet fragile liminal epicentre involves every person and community who interprets and experiences the living faith mediated by these texts, and should serve - as I have mentioned earlier - the unity of the church, directly and indirectly. For this reason, 'regular' and 'professional' readers biblical scholars, systematic and practical theologians - all share the moral obligation to engage the creative tension between the dynamics of these texts and the multiple needs, suffering, fears and hopes of the present-day audiences. Those who have chosen to inhabit their strange, alternative world, desperately need one another in the process of sensible understanding (cf Mouton 2006:77-80).

As New Testament scholars we cannot assume that our work will be of use to the church and its public witness. We should rather ask whether the church (still) needs us, and whether we are all indispensable. In the past, we could not assume we were of use (cf Smit 1992, 1994b, 1996). I am inclined to think neither can we now. ${ }^{10}$

The interactive epicentre of New Testament Studies is a surprisingly rich yet complex, noisy and even messy space (Mouton 2006:50-60). In order for New Testament scholars to contribute to a sense-ability, being heard, depicting reality, being life-affirming, problem-solving and a community-building enterprise (cf van Huyssteen 1986:169-187), we need to become 'recipients' ourselves. We have to listen carefully and prayerfully to what the New Testament texts tried to accomplish, and pay special attention to their intended functions in varying contexts over time.

If such an understanding at the core of New Testament Studies is required as requisite for its pathos, persuasive drive

10.A crucial question today is how the culturally-bound alternative world of those ancient texts may be brought into relation with (post)modern theological and moral challenges. To respond with sensitivity to their implied rhetorical function is to account for their life-giving authority amid their cultural-historical biases. To allow for interpretations and experiences of a living God who is constantly revealed in new and surprising ways (Hays 1989:32-33; Meeks 1993:217-219), later audiences are challenged to account for their patriarchal contexts and language audiences are challenged to account for their patriarchal contexts and language, and to create the inclusive language needed to make sense of new faith experiences (cf van Huyssteen 1986:173-187). Anything less would confine the God of Jesus Christ and the Spirit to the boundaries of ancient texts in ways contradictory to their own dynamic nature. Committed to the authority of scripture as liberating practice for all people - in all times and places - interpretive communities, including New Testament guilds and societies, are called to critically examine their exegetical, hermeneutical and theological traditions in terms of the ethical effects they had and still have in the lives of people. 
and healing power, it becomes a deeply sacred, sacramental and liturgical subject. I want to acknowledge Wentzel van Huyssteen's hermeneutic by suggesting that New Testament interpreters develop a hermeneutic of listening. The New Testament writings metaphorically refer to receiving the gospel as 'hearing the word'. ${ }^{11} \mathrm{~A}$ 'hermeneutic of listening' implies the willingness to hear mindfully - with openness and receptivity. ${ }^{12}$ It includes paying attention to, acknowledging, and submitting to the paradoxical authority of God's words in human language. As such it would be in accordance not only to the nature of these texts, but also to the Reformed principle of biblical reading as discerning the voice of the living God. A hermeneutic of listening reclaims the life-changing, transformative potential of the New Testament writings as an invitation to attain a healed and healing body of Christ. It will embrace and sanction (public) responsibility and action, knowing that those texts are the result of actions and intended to create action (Snodgrass 2002:27). A hermeneutic of listening will consider all the voices represented in New Testament interpretation, consciously hearing those voices which are considered unimportant in the past, including the silenced voices within the biblical texts. It challenges us to live patiently and humbly with the discomfort of risking to remember, to forgive and to hope. ${ }^{13}$

Biblical scholars have much to learn from Van Huyssteen's embodiment of relationality and risk as the foundation for his bold thinking beyond boundaries. A hermeneutic of listening gives priority to the imaginative possibilities of God's liberating, healing love over the broken realities of our lives and world. It allows for moral confidence instead of absolute certainty. Perhaps receivers of the biblical texts today should be challenged - like the early Christians - to remain open to be surprised by that which they do not understand.

\section{Acknowledgements}

As indicated in footnote 1, the article is a shortened and reworked version of my inaugural lecture as professor in New Testament Studies in the Faculty of Theology, Stellenbosch University, on 22 March 2005. It was published under the title 'The Pathos of New Testament Studies' in

11.Right through scripture priority is given to acts of hearing, of recognising, of discerning-particularly in the sense of receiving, of believing, of being moved and
persuaded by, of submitting to, of obeying God's will (cf the Shema in Dt 6:4, persuaded by, of submitting to, of obeying God's will (cf the Shema in Dt 6:4,
foundational to Old Testament covenantal thinking, and affirmed by Jesus as the greatest command' - Mt 22:37; Snodgrass 2002:11-12, 23-27).

12.In this context Snodgrass refers to Ricoeur's explanation of 'hearkening' (l'écoute) as pre-ethical obedience. It is a stance prior to hearing, a mode of being that is no yet a mode of doing (cf n.3). "The one "hearkening" is no longer master, and this situation of nonmastery is the origin of obedience and freedom. This is an ethics of the desire to be. This desire to be ... enables hearing' (Snodgrass 2002:29). Ricoeur comments further that silence is the origin of hearkening and obedience (referred to by Snodgrass 2002:29 n.75)

13.In concurrence with Denise Ackermann's relational anthropology (1991:100-103, 1992:16-23) and feminist theology as liberating praxis (1994:201-208), the key words in a hermeneutic of listening are 'relationality' and 'risk'. 'Relationality as basis for a transformative view of humanity is ... concerned with our relationships with ourselves, with one another, with God and with our environment' (Ackermann 1991:102). It is the opposite of alienation, apathy, and exclusion. 'Risk' refers to the courage, energy, and commitment required to deal with the deeply entrenched power of patriarchy and other forms of oppression (Ackermann 1994:207; cf v power of patriarchy and other forms of oppression (Ackermann 1994:207; cf v
Huyssteen 1987:42-51). For Christian believers, Christ is the model with regard to this stereoscopic vision of transformation.
Theologia Viatorum 30/1 (2006), 50-86. It has been reworked in the light of Wentzel van Huyssteen's influence on my thinking as mentor, colleague and friend.

\section{Competing interests}

The author declares that she has no financial or personal relationships that may have inappropriately influenced her in writing this article.

\section{Author's contributions}

E.M. is the sole author of this article.

\section{Ethical considerations}

This article followed all ethical standards for research without direct contact with human or animal subjects.

\section{Funding information}

This research received no specific grant from any funding agency in the public, commercial, or not-for-profit sectors.

\section{Data availability}

Data sharing is not applicable to this article as no new data were created or analysed in this study.

\section{Disclaimer}

The views and opinions expressed in this article are those of the author and do not necessarily reflect the official policy or position of any affiliated agency of the author.

\section{References}

Ackermann, D., 1991, 'Being woman, being human', in D. Ackermann, J.A. Draper \& E. Mashinini (eds.), Women hold up half the sky: Women in the church in Southern Africa, pp. 93-105, Cluster Publications, Pietermaritzburg.

Ackermann, D., 1992, 'Defining our humanity: Thoughts on a feminist anthropology', JTSA 79, 13-23.

Ackermann, D., 1994, 'Faith and feminism: Women doing theology', in J. De Gruchy \& C. Villa-Vicencio (eds.), Doing theology in context: South African perspectives, pp. 197-211, Orbis Books, Maryknoll, NY.

Botha, J., 1994a, 'The Bible and ethics', in C. Villa-Vicencio \& J.W. De Gruchy (eds.), Doing ethics in context: South African perspectives, pp. 36-45, David Philip, Cape Town.

Botha, J., 1994b, Subject to whose authority? Multiple readings of Romans 13, Scholars Press, Atlanta, GA.al

Fowl, S.E. \& Jones, L., 1991, Reading in communion: Scripture and ethics in Christian Life, SPCK, London.

Hauerwas, S., 1981, A community of character: Toward a constructive social ethic, University of Notre Dame, Notre Dame, IN.

Hauerwas, S., 1985a, 'The gesture of a truthful story', Theology Today 42(2), 181-189. https://doi.org/10.1177/004057368504200204

Hauerwas, S., 1985b, Character and the Christian life: A study in theological ethics, Trinity University, San Antonio, TX.

Hays, R.B., 1989, Echoes of scripture in the letters of Paul, Yale University, New Haven, CT.

Johnson, L.T., 1999, The writings of the New Testament: An interpretation, rev. edn., Fortress, Minneapolis, IN.

Lategan, B.C., 1982, 'Inleiding tot de Uitlegging van het Nieuwe Testament', in A.F.J. Klijn (red.), Inleiding tot de studie van het Nieuwe Testament, pp. 47-70, J.H. Kok, Kampen.

Lategan, B.C., 1989, 'Introduction: Coming to grips with the reader', Semeia 48, 3-17.

Lategan, B.C., 1992, 'Hermeneutics', in D.N. Freedman (ed.), The anchor Bible dictionary, vol. 3, pp. 149-154, Doubleday, New York, NY. 
Lategan, B.C., 1994, 'Revisiting text and reality', Neotestamentica 28(3), 121-135. Lategan, B.C., 1996, 'Imagination and transformation: Ricoeur and the role of imagination', Scriptura 58(3), 213-232.

McFague, S., 1982, Metaphorical theology: Models of God in religious language Fortress, London.

Meeks, W.A., 1986, The moral world of the first Christians, Westminster Philadelphia, PA.

Meeks, W.A., 1993, The origins of Christian morality: The first two centuries, Yale University, New Haven, CT.

Mouton, E., 2001, 'A rhetoric of theological vision? On Scripture's reorienting power in the liturgy of (social) life', Neotestamentica 35(1-2), 111-127.

Mouton, E., 2002, Reading a New Testament document ethically, Society of Biblical Literature, Atlanta, GA.

Mouton, E., 2003, '(Re)describing reality? The transformative potential of Ephesians across times and cultures', in A.-J. Levine \& M. Blickenstaff (eds.), A feminist companion to the Deutero-Pauline Epistles, pp. 59-87, The Pilgrim Press, Cleveland, $\mathrm{OH}$.

Mouton, E., 2006, 'The Pathos of New Testament Studies', Theologia Viatorum Journal of Theology and Religion in Africa 30(1), 50-86.

Patte, D., 1995, Ethics of biblical interpretation: A reevaluation, Westminster John Knox, Louisville, KY.

Phiri, I.A., 2004, 'Life-giving and life-affirming spirituality: A perspective from Africa', Reformed World 54(2), 107-111.

Ricoeur, P., 1975, 'Biblical hermeneutics', Semeia 4, 29-148.

Ricoeur, P., 1976, Interpretation theory: Discourse and the surplus of meaning, Texas Christian University, Fort Worth, TX.

Ricoeur, P., 1980, Essays on biblical interpretation, ed. L.S. Mudge, Fortress, Philadelphia, PA.

Schneiders, S.M., 1991, The revelatory text: Interpreting the New Testament as sacred scripture, HarperSanFranciso, New York, NY.

Schüssler Fiorenza, E., 1988, 'The ethics of Biblical interpretation: Decentering biblical scholarship', JBL 107(1), 3-17. https://doi.org/10.2307/3267820

Smit, D.J., 1990a, 'The ethics of interpretation - New voices from the USA', Scriptura 33, 16-28. https://doi.org/10.7833/33-0-1879

Smit, D.J., 1990b, 'The ethics of interpretation - And South Africa', Scriptura 33, 29-43. https://doi.org/10.7833/33-0-1880
Smit, D.J., 1991a, 'Wat beteken 'die Bybel sê'? 'n Tipologie van leserkonstrukte', Hervormde Teologiese Studies 47(1), 167-185. https://doi.org/10.4102/hts. v47i1.2366

Smit, D.J., 1991b, 'The Bible and ethos in a New South Africa', Scriptura 37, 51-67. https://doi.org/10.7833/37-0-1814

Smit, D.J., 1992, 'Oor “Nuwe-Testamentiese etiek," die Christelike lewe en Suid-Afrika vandag', in C. Breytenbach \& B. Lategan (reds.), Geloof en opdrag: Perspektiewe op die etiek van die Nuwe Testament, Scriptura S9a, 303-325.

Smit, D.J., 1994a, 'Morality and individual responsibility', JTSA 89, 19-30.

Smit, D.J., 1994b, 'A story of contextual hermeneutics and the integrity of New Testament interpretation in South Africa', Neotestamentica 28(2), 265-289.

Smit, D.J., 1996, 'Saints, disciples, friends? Recent South African perspectives on Christian ethics and the New Testament', Neotestamentica 30(2), 451-464.

Smit, D.J., 1998a, 'Biblical hermeneutics: The first 19 centuries', in S. Maimela \& A. König (eds.), Initiation into theology: The rich variety of Theology and Hermeneutics, pp. 275-296, J.L. Van Schaik, Pretoria.

Smit, D.J., 1998b, 'Biblical hermeneutics: The 20th century', in S. Maimela \& A. König (eds.), Initiation into theology, pp. 297-317, J.L. Van Schaik, Pretoria.

Snodgrass, K., 2002, 'Reading to hear: A hermeneutics of hearing', Horizons in Biblical Theology 24, 1-32.

Taylor, M.K., 1990, Remembering Esperanza: A cultural-political theology for North American Praxis, Orbis Books, Maryknoll, NY.

Thiselton, A.C., 1992, New horizons in hermeneutics: The theory and practice of transforming biblical reading, Zondervan Publishing House, Grand Rapids, MI.

Tödt, H.E., 1977, 'Versuch zu einer Theorie ethischer Urteilsfindung', Zeitschrift für Evangelische Ethik 21, 81-93. https://doi.org/10.14315/zee-1977-0110

Van Gennep, A., 1960, The rites of passage, transl. M.B. Vizedom \& G.L. Caffee, Routledge \& Kegan Paul, London.

Van Huyssteen, J.W., 1986, Teologie as kritiese geloofsverantwoording: Teorievorming in die sistematiese teologie, Raad vir Geesteswetenskaplike Navorsing, Pretoria.

Van Huyssteen, J.W., 1987, The realism of the text: A perspective on biblical authority, UNISA, Pretoria.

Van Huyssteen, J.W., 1997, Essays in postfoundationalist theology, Wm. B. Eerdmans, Grand Rapids, MI

Vorster, W.S., 1989, 'The reader in the text: Narrative material', Semeia 48, 21-39.

West, G.O. \& Dube, M.W. (eds.), 2000, The Bible in Africa: Transactions, trajectories and trends, Brill, Leiden. 